\title{
Pengaruh Model Pembelajaran Contextual Teaching and Learning (CTL) Terhadap Hasil Belajar Siswa Pada Pembelajaran IPA Materi Sistem Pencernaan Manusia
}

\author{
Ni Wayan Sri Parwasih ${ }^{1}$, Zusje W. M. Warouw ${ }^{2}$ \\ 1,2Jurusan Pendidikan IPA, FMIPA, Universitas Negeri Manado \\ "e-mail: sriparwasihwayan@gmail.com
}

\begin{abstract}
Abstrak. Penelitian ini dilakukan untuk mengetahui pengaruh model pembelajaran Contextual Teaching and Learning (CTL) terhadap hasil belajar siswa pada materi sistem pencernaan manusia kelas VIII SMP Swadharma Mopugad. Desain yang digunakan dalam penelitian ini adalah pretest-posttest control-group design. Populasi dalam penelitian ini adalah siswa kelas VIII SMP Swadharma Mopugad yang terdiri dari 2 kelas. Sampel dalam penelitian ini diambil dengan menggunakan random sampling yaitu 1 kelas sebagai kelas kontrol dan 1 kelas sebagai kelas eksperimen dengan jumlah masing-masing kelas 25 siswa. Uji prasyarat menggunakan uji normalitas dan homogenitas, teknik analisis data menggunakan uji-t, dalam pengujian tersebut diperoleh $t_{\text {hitung }}=10,70>t_{\text {tabel }}=1,708$. Kesimpulannya yaitu model CTL berpengaruh terhadap hasil belajar siswa.
\end{abstract}

Kata kunci: model pembelajaran CTL, hasil belajar, sistem pencernaan manusia

\begin{abstract}
This research was conducted to determine the effect of the Contextual Teaching and Learning (CTL) model on student learning outcomes on the human digestive system material for grade VIII SMP Swadharma Mopugad. The design used in this study was a pretest-posttest control-group design. The population in this study were students of class VIII SMP Swadharma Mopugad which consisted of 2 classes. The sample in this study was taken using random sampling, namely 1 class as the control class and 1 class as the experimental class with a total of 25 students for each class. The prerequisite test used the normality and homogeneity test, the data analysis technique used the t-test in the test, it was obtained $t_{\text {count }}=10.70>t_{\text {table }}=1.708$. The conclusion is that the model CTL has an effect on student learning outcomes.
\end{abstract}

Keywords: CTL model, learning outcomes, human digestive system

Diterima 14 Mei 2020 | Disetujui 10 Juni 2020 | Diterbitkan 30 Juni 2020

\section{PENDAHULUAN}

Unsur utama dalam mengajar adalah merangsang dan mengarahkan siswa belajar, karena proses belajar pada hakikatnya merupakan proses interaksi antara guru dan peserta didik. Proses ini akan berkembang sempurna sampai hasil yang optimal, dan hal ini dapat terjadi bila guru dan siswa memiliki motivasi yang tinggi (Subianto, 2001).

Sebagian besar peserta didik belum dapat menangkap makna dari apa yang mereka peroleh dari pembelajaran untuk dapat diterapkan dalam kehidupan sehari-hari. Hal ini sesuai dengan kenyataan bahwa pada umumnya peserta didik tidak dapat menghubungkan apa yang telah mereka pelajari dengan cara pemanfaatan pengetahuan tersebut dikemudian hari. Dalam hal ini pendidikan masih didominasi oleh pemandangan bahwa pengetahuan sebagai perangkat fakta-fakta yang harus dihafal.

Proses belajar mengajar terdapat beberapa metode yang dapat merangsang 
kreativitas dan minat siswa terhadap pelajaran, salah satunya dengan pembelajaran menggunakan model kontekstual. Contextual Teaching and Learning (CTL) adalah suatu model pembelajaran yang mendorong siswa untuk memahami makna materi pelajaran yang dipelajarinya dengan mengaitkan materi tersebut dengan konteks kehidupan mereka sehari-hari (konteks pribadi, sosial, dan kultural) sehingga siswa memiliki pengetahuan dan keterampilan yang secara fleksibel dapat diterapkan (ditransfer) dari satu permasalahan (Rusman, 2014).

Pada dasarnya CTL merupakan konsep pembelajaran yang membantu guru dalam mengaitkan materi pelajaran dengan kehidupan nyata siswa, dan memotivasi siswa membuat hubungan antara pengetahuan yang dipelajarinya dengan kehidupan sehari-hari, sehingga mendorong siswa untuk dapat menerapkannya dalam kehidupan meraka (Khusniati, 2012).

Hasil belajar adalah perubahan yang mengakibatkan manusia berubah dalam sikap dan tingkah lakunya (Purwanto, 2010). Aspek perubahan itu mengacu kepada taksonomi tujuan pengajaran yang dikembangkan oleh Bloom, Simpson dan Harow mencakup aspek kognitif, afektif dan psikomotorik. Proses pengajaran merupakan sebuah aktivitas sadar yang membuat siswa belajar. Proses sadar mengandung implikasi bahwa pengajaran merupakan sebuah proses yang direncanakan untuk mencapai tujuan pengajaran (goal directed).

Hasil belajar merupakan kemampuan yang diperoleh individu setelah proses belajar berlangsung, yang dapat memberikan perubahan tingkah laku baik pengetahuan, pemahaman, sikap dan keterampilan siswa sehingga menjadi lebih baik dari sebelumnya (Ngalim, 2002).

Hasil observasi ditemukan kurangnya keaktifan siswa dalam mengikuti proses pelajaran khususnya pada mata pelajaran IPA hal ini terlihat dari siswa yang kurang memperhatikan guru saat menjelaskan pelajaran, siswa tidak antusias dalam mengikuti pelajaran kebanyakan siswa hanya bermain di kelas sehingga siswa tidak mampu memahami apa yang telah diberikan oleh guru dan mengembangkan potensi yang ada pada dirinya. Faktor tersebut disebabkan oleh beberapa hal seperti: variasi penggunaan metode dan model pembelajaran masih minim, kebanyakan metode yang digunakan ialah diskusi, dan terbatasnya buku panduan mata pelajaran IPA.

Fakta dari permasalahan yang terjadi disekolah tersebut sangatlah mempengaruhi rata-rata hasil belajar yang diperoleh adalah 6,5 dari rentangan nilai 0 sampai dengan 10 , sedangkan Kriteria Ketuntasan Maksimum (KKM) untuk pelajaran IPA di sekolah tersebut adalah adalah 70 . Sehingga hasil belajar belum memenuhi KKM.

Berdasarkan masalah diatas perlunya perubahan proses pembelajaran, oleh sebab itu diperlukan suatu model pembelajaran CTL yang membantu guru dalam mengaitkan antara materi yang diajarkan dengan situasi dunia nyata dan mendorong peserta didik membuat pengetahuan yang dimilikinya dengan kehidupan mereka sebagai anggota keluarga maupun masyarakat.

\section{METODE PENELITIAN}

Penelitian ini telah dilaksanakan pada semester ganjil tahun ajaran 2019/2020 di SMP Swadharma Mopugad, pada tanggal 26 November sampai 06 desember 2019.

Populasi dalam penelitian ini adalah seluruh siswa kelas VIII SMP Swadharma Mopugad semester ganjil tahun ajaran 2019-2020 yang terdiri dari 2 (dua) kelas.

Sampel dalam penelitian ini adalah dua kelas yaitu kelas VIII-A dan kelas VIII-B. kelas VIII A sebagai kelas kontrol dengan jumlah siswa 25 dan kelas VIII-B sebagai kelas eksperimen dengan jumlah siswa 25. Penentuan kelas yang telah menjadi subjek penelitian dilakukan dengan melakukan cabut undi kertas.

Jenis penelitian ini dikategorikan sebagai penelitian eksperimen semu dengan kelompok yang diberi pretest dan 
posttest. Rancangan penelitian yang digunakan adalah pretest-posttest controlgroup design

Instrumen yang digunakan untuk mengukur kemampuan hasil belajar siswa yaitu tes yang digunakan untuk mengukur sejauh mana siswa mampu untuk memahami pelajaran yang diberikan. Observasi untuk memperoleh data yang diperlukan yaitu observasi dan tes. Tes yang digunakan yaitu tes essay dan tes objektif. Tes diberikan sebelum dan sesudah siswa mempelajari materi dengan menerapkan model CTL.

Penelitian ini terdapat dua variabel, yakni: variabel bebas (independent) dan variabel terikat (dependent). Prosedur penelitian ini terdapat beberapa tahap pelaksanaan yaitu: menentukan kelas yang akan dijadikan sampel penelitian yang terdiri dari kelas eksperimen dan kelas kontrol, kemudian melaksanakan pretest pada kelas eksperimen dan kelas kontrol untuk mengukur pengetahuan awal siswa, kemudian melaksanakan proses pembelajaran kelas eksperimen dan kelas kontrol, selanjutnya melaksanakan posttest pada kelas eksperimen dan kelas kontrol dengan soal yang sama dengan pretest. Setelah itu tahap penarikan kesimpulan yaitu: menganalisa data, membahas data yang sudah dianalisa, dan menarik kesimpulan.

Data hasil belajar siswa dikumpulkan dengan memberikan pretest dan posttest. Data yang digunakan yaitu tes. Tes adalah instrument atau alat ukur untuk mengumpulkan data tentang subjek penelitian dengan cara pengukuran, misalnya untuk mengukur subjek dalam menguasai materi pelajaran yang telah diberikan digunakan tes tertulis.

Apabila data penelitian telah dipeoleh, maka kemudian dilanjutkan dengan tabulasi data untuk menghitung statistik deskriptifnya. Untuk menguji hipotesis terlebih dahulu dilakukan uji prasyarat yaitu uji normalitas dan uji homogenitas (Mursalin, 2016).

\section{HASIL DAN PEMBAHASAN}

Uji normalitas dilakukan agar dapat mengetahui kedua kelas tersebut berdistribusi normal atau tidak. Pengujian normalitas data menggunakan microsoft excel dengan pendekatan statistika uji Lilifors dengan taraf nyata $a=0,05$ dengan $n=25$ dapat dilihat pada Tabel 1 .

Tabel 1. Uji normalitas hasil belajar

\begin{tabular}{lll}
\hline Kelompok & Lhitung & Ltabel \\
\hline Eksperimen & 0.7481446 & 0.9772000 \\
Kontrol & 0.8292361 & 0.9772000 \\
\hline \multicolumn{3}{c}{ Normal } \\
\hline
\end{tabular}

Pengujian homogenitas dilakukan agar dapat mengetahui varians dari kelas eksperimen dan kelas kontrol adalah sama atau tidak. Data homogenitas terdapat pada keragaman varians atau standar deviasi dari data tersebut. Data yang diuji adalah data pretest dari kedua kelompok. Penelitian ini dilakukan uji homogenitas menggunakan uji $F$ dapat dilihat pada Tabel 2 .

Tabel 2. Uji homogenitas hasil belajar

\begin{tabular}{lll}
\hline \multirow{2}{*}{ Data } & \multicolumn{2}{c}{ Kelas } \\
\cline { 2 - 3 } & Eksperimen & Kontrol \\
\hline Rata-rata & 52.00 & 53.00 \\
Varians (S & 100.000 & 120.83 \\
F & & 1.73 \\
$\mathrm{~F}_{\text {tabel }}$ ) & \multicolumn{2}{c}{3.39} \\
\hline \multicolumn{3}{c}{ Homogen } \\
\hline
\end{tabular}

Berdasarkan hasil pengujian normalitas kedua kelompok berdistribusi normal dan bersifat homogenitas, maka pengujian hipotesis dapat dilakukan dengan menggunakan uji-t. data yang diuji adalah data selisih dari hasil posttest dan pretest kedua kelompok yaitu kelas eksperimen dan kelas kontrol. Pengujian data menggunakan microsoft excel yang dapat dilihat pada Tabel 3.

Tabel 3. Uji hipotesis hasil belajar

\begin{tabular}{lcl}
\hline \multicolumn{3}{c}{ Uji hipotesis (nilai selisih) } \\
\hline $\mathrm{t}_{\text {stat }}$ & 10.70 & nilai thitung \\
$\mathrm{t}_{\text {cristical one-tail }}$ & 1.708 & nilai $\mathrm{t}_{\text {tabel }}$ \\
\hline
\end{tabular}

Berdasarkan hasil perhitungan yang ada $t_{\text {hitung }}=10.70>t_{\text {tabel }}=1.708$ berarti 
penggunaan model CTL berpengaruh terhadap kemampuan hasil belajar siswa dibandingkan dengan menggunakan model pembelajaran konvensional.

\section{Pengaruh CTL terhadap Hasil Belajar}

Penggunaan model pembelajaran CTL bahwa terdapat pengaruh terhadap hasil belajar siswa pada mata pelajaran IPA materi sistem pencernaan manusia di SMP Swadharma Mopugad, dimana CTL memiliki keungulan akan tumbuhnya suasana demokratis dalam pembelajaran sehingga terjadi dialog dan diskusi untuk saling belajar di antara peserta didik dan menambah wawasan pikiran serta pengetahuan bagi pendidik karena sesuatu yang dialami dan disampaikan peserta didik mungkin belum diketahui sebelumnya oleh peserta didik. Dalam pelaksanaan pembelajaran guru memberikan soal-soal yang nantinya akan dijadikan hasil dari belajar siswa yang berupa soal posttest dan pretest, dan ada pula penilian sejauh mana siswa aktif serta antusias dalam mengikuti pelajaran didalam kelas. Pendekatan CTL adalah suatu pendekatan pembelajaran yang dimulai dengan mengaitkan materi yang dipelajari dengan situasi dunia nyata siswa dan mendorong siswa membuat hubungan antara pengetahuan yang dimilikinya dengan penerapannya dalam kehidupan mereka sehari-hari.

Prinsip dari model CTL yaitu memberikan kebebasan kepada peserta didik dalam mengembangkan pengetahuannya berdasarkan pengetahuan awal yang telah diperoleh sebelumnya melalui pengalaman langsung sehingga peserta didik terlibat aktif dalam pembelajaran yang kemudian menjadikan pembelajaran menjadi lebih bermakna.

Model CTL merupakan rangkaian tahapan kegiatan pembelajaran yang diorganisasi sedemikian rupa sehingga siswa dapat menguasai kompetensikompetensi yang harus dicapai dalam pembelajaran dengan jalan berperan aktif. Langkah-langkah pembelajaran CTL meliputi; kontruktivis, inkuiri, bertanya, masyarakat belajar, pemodelan, refleksi, dan penilaian sebenarnya. Pada tahap kontruktivis, yaitu guru membantu merangsang pemikiran siswa dan membantu mengakses pengetahuan sebelumnya dengan memberikan beberapa pertanyaan ataupun mengamati gambar terkait dengan materi yang akan dibelajarkan, sehingga siswa akan termotivasi dan tertarik perhatiannya untuk mengikuti pelajaran. Tahap inkuiri, pada tahap ini guru memfasilitasi siswa untuk mencari dan mengkaji informasi yang didapat melalui buku sumber, pengamatan, media lainnya. Dengan siswa melakukan kegiatan inkuiri, pemahaman siswa terhadap materi pelajaran akan lebih bermakna dan lebih melekat pada memorinya, karena siswa sendiri yang menemukan apa yang mereka pelajari. Tahap bertanya, pada tahap ini siswa membuat pertanyaan-pertanyaan terkait dengan temuan yang didapatkan yang akan diajukan kepada guru, kemudian guru akan memberikan penjelasan terkait dengan pertanyaan siswa (Wiraguna, 2014).

Menurut Piaget dalam Purwanto (2017), belajar adalah adaptasi yang holistic dan bermakna yang datang dari dalam diri seseorang terhadap situasi baru sehingga mengalami perubahan yang relative permanen. Jean Piaget menyebut pula hasil belajar adalah prestasi belajar. Sedangkan Ngalim Purwanto menjelaskan bahwa belajar adalah suatu proses yang menimbulkan terjadinya suatu perubahan atau pembaharuan dalam tingkah laku atau kecerdasan. Dua pengertian tersebut saling melengkapi tentang hasil dari proses belajar. Hasil belajar berupa prestasi belajar dan perubahan tingkah laku atau kecerdasan.

Maisaroh dalam Sudjana (2011), menyatakan hasil belajar adalah prestasi dari suatu kegiatan yang telah dikerjakan, diciptakan, baik secara individu maupun tim. Secara garis besar membagi hasil belajar menjadi tiga ranah, yaitu : Ranah kognitif berkenaan dengan hasil belajar intelektual yang terdiri dari enam aplikasi, analisis, sintesis, dan 
evaluasi. Ranah afektif berkenaan dengan sikap yang terdiri dari lima aspek yaitu penerimaan, jawaban, penilaian, organisasi, dan internalisasi. Ranah psikomotorik berkenaan dengan hasil belajar berupa keterampilan dan kemampuan bertindak.

Ketiga ranah tersebutlah yang akan menjadi objek penilaian hasil belajar dan diantara ketiga ranah tersebut, ranah kognitiflah yang mendapat perhatian paling besar bagi seorang guru atau guru. Karena pada ranah kognitif inilah siswa akan terlihat kemampuannya dalam menguasai bahan pelajaran ataukah tidak. Berdasarkan teori-teori diatas dapat disimpulkan bahwa hasil belajar adalah hasil yang diperoleh seseorang dalam proses kegiatan belajar mengajar, dan hasil belajar tersebut dapat berbentuk kognitif, afektif, dan psikomotorik yang penilaiannya melalui tes.

Hasil penelitian ini didukung pada penelitian Merta (2013) yang menyatakan bahwa terdapat perbedaan yang signifikan penguasaan konsep antara siswa yang belajar menggunakan model kontekstual dan siswa yang menggunakan model pembelajaran langsung. Penguasaan konsep siswa yang belajar menggunakan model pembelajaran kontekstual lebih baik daripada siswa yang belajar menggunakan model pembelajaran berlangsung.

\section{KESIMPULAN}

Setelah dilakukan analisa terhadap data yang telah dikumpulkan maka dapat disimpulkan bahwa, terdapat pengaruh model pembelajaran Contextual Teaching and Learning (CTL) terhadap hasil belajar siswa pada materi Sistem Pencernaan Manusia di SMP Swadharma Mopugad, rata-rata dari hasil belajar kelas eksperimen 26,67 dan dari kelas kontrol 9.

\section{DAFTAR PUSTAKA}

Khusniati, M. (2012). Pendidikan Karakter Melalui Pembelajaran IPA. Jurnal Pendidikan IPA Indonesia, 1(2), 204-210.
Maisaroh \& Rostrieningsih. (2010). Peningkatan Hasil Belajar Siswa dengan Menggunakan Metode Pembelajaran Active Learning Tipe Quiz. Jurnal Ekonomi \& Pendidikan, 8(2), 157-172.

Merta Luh, M. (2013). Pengaruh Model Pembelajaran Kontekstual Terhadap Penguasaan Konsep Koloid dan Sikap Ilmiah Siswa. Jurnal Pendidikan dan Pengajaran, 1(46), 9-19.

Mursalin Wan. (2016). Pengaruh Penggunaan Model Pembelajaran Children Learning In Science Terhadap Hasil Belajar IPS Terpadu Di SMP Negeri 1 Meureudu. Jurnal Ilmiah Mahasiswa Pendidikan Geografi FKIP Unsyiah. 1(2), 131-144.

Ngalim Purwanto, M. (2002). Psikologi Pendidikan. Bandung: Remaja Rosda Karya.

Purwanto. (2010). Evaluasi Hasil Belajar. Surakarta: Pustaka Pelajar.

Rusman. (2010). Model-model Pembelajaran (Mengembangkan Profesionalisme Guru Edisi Kedua). Jakarta: Raja Grafindo Persada.

Subianto. (2001). Teori dan Aplikasi Paikem. Yogyakarta: Pustaka Belajar.

Wiraguna. (2014). Pengaruh Pendekatan CTL Berbasis Kearifan Lokal Terhadap Hasil Belajar IPA Siswa. Jurnal Mimbar PGSD Universitas Pendidikan Ganesha, 2(1), 1-9. 